June 2004 • NREL/CP-500-35353

\title{
Parallel Operation of Wind Turbine, Fuel Cell, and Diesel Generation Sources
}

\section{Preprint}

\author{
E. Muljadi \\ C. Wang \\ M.H. Nehrir
}

To be presented at the IEEE-Power Engineering Society General Meeting

Denver, Colorado

June 6 - June 10, 2004
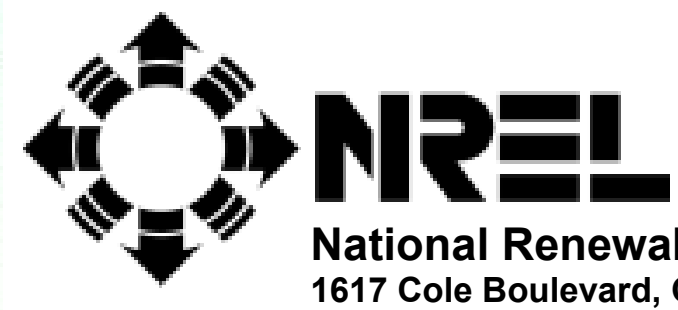

National Renewable Energy Laboratory 1617 Cole Boulevard, Golden, Colorado 80401-3393 303-275-3000 • www.nrel.gov

Operated for the U.S. Department of Energy

Office of Energy Efficiency and Renewable Energy

by Midwest Research Institute $\bullet$ Battelle

Contract No. DE-AC36-99-G010337 


\section{NOTICE}

The submitted manuscript has been offered by an employee of the Midwest Research Institute (MRI), a contractor of the US Government under Contract No. DE-AC36-99G010337. Accordingly, the US Government and MRI retain a nonexclusive royalty-free license to publish or reproduce the published form of this contribution, or allow others to do so, for US Government purposes.

This report was prepared as an account of work sponsored by an agency of the United States government. Neither the United States government nor any agency thereof, nor any of their employees, makes any warranty, express or implied, or assumes any legal liability or responsibility for the accuracy, completeness, or usefulness of any information, apparatus, product, or process disclosed, or represents that its use would not infringe privately owned rights. Reference herein to any specific commercial product, process, or service by trade name, trademark, manufacturer, or otherwise does not necessarily constitute or imply its endorsement, recommendation, or favoring by the United States government or any agency thereof. The views and opinions of authors expressed herein do not necessarily state or reflect those of the United States government or any agency thereof.

Available electronically at http://www.osti.gov/bridge

Available for a processing fee to U.S. Department of Energy and its contractors, in paper, from:

U.S. Department of Energy

Office of Scientific and Technical Information

P.O. Box 62

Oak Ridge, TN 37831-0062

phone: 865.576 .8401

fax: 865.576 .5728

email: mailto:reports@adonis.osti.gov

Available for sale to the public, in paper, from:

U.S. Department of Commerce

National Technical Information Service

5285 Port Royal Road

Springfield, VA 22161

phone: 800.553 .6847

fax: 703.605.6900

email: orders@ntis.fedworld.gov

online ordering: http://www.ntis.gov/ordering.htm 


\title{
Parallel Operation of Wind Turbine, Fuel Cell, and Diesel Generation Sources
}

\author{
E. Muljadi ${ }^{1}$, C. Wang ${ }^{2}$, M.H. Nehrir ${ }^{2} 3$
}

\begin{abstract}
We investigated a small isolated hybrid power system that used a parallel combination of dispatchable and nondispatchable power generation sources. The non-dispatchable generation came from a nature-dependent wind turbine, and the dispatchable generations were a fuel cell and a diesel generator. On the load side, the non-dispatchable portion was the village load, and the dispatchable portion was the energy storage, which could be in many different forms (e.g., space/water heater, electrolysis, battery charger, etc.) The interaction among different generation sources and the loads was investigated. Simulation results showed the effect of the proposed system on voltage and frequency fluctuations.
\end{abstract}

Index Terms - wind turbine, diesel, fuel cell, power generation, parallel operation, hybrid generation

\section{INTRODUCTION}

$\mathrm{S}_{\mathrm{i}}^{\mathrm{i}}$ ince ancient history, wind-turbine technology has been used to improve the quality of life. For example, people have used wind power to pump water or mill grains. More recently, wind turbines have been used for water or oil pumping [1], battery charging, or utility power generation. An important aspect of wind turbine power generation is that it does not pollute air or water. Wind power is also well suited for remote areas with low population, where there is little incentive for a utility to build transmission lines.

Hybrid power systems have been used very successfully to reduce pollution and to conserve diesel fuel consumption [23]. For this paper, we analyzed a hybrid power system consisting of a $225-\mathrm{kW}$ wind turbine, a $400-\mathrm{kW}$ diesel generator, and a $75-\mathrm{kW}$ fuel cell array to provide power to a village. A dispatchable load was used to help balance the power in the system. An example of dispatchable load to regulate system frequency can be found in reference [4].

In the following sections, we describe the overall system and each individual generation source, as well as the interaction among the generation sources and loads.

\section{SYSTEM CONFIGURATION}

A block diagram of the system is shown in Fig. 1. The wind turbine was operated with a constant frequency generator (induction generator) with a capacity of $225 \mathrm{~kW}$ about 1200 rpm. It was a stall-regulated wind turbine. The diesel engine had a rated capacity of $400 \mathrm{~kW}$. The fuel cell was rated at 75 $\mathrm{kW}$, and the local loads were mostly residential and water

\footnotetext{
${ }_{2}^{1}$ National Renewable Energy Laboratory, Golden, CO 80401

2 Montana State University, Department of Electrical \& Computer Engineering, Bozeman, MT 59717

${ }^{3}$ This article is offered by the Midwest Research Institute (MRI) employee under U.S. Government Contract No. DE-AC36-99GO10337. Government and MRI retain non-exclusive, royalty-free license to publish or reproduce published articles or allow others to do so for Government purposes.
}

pump. A dispatchable load was available to balance out the real power in the system.

The diesel generator provided a smooth generation, whereas the output power of the wind turbine generation depended on the wind velocity. The wind velocity was reflected in the power generation; for example, if the wind varied smoothly, the output also changed smoothly. On the other hand, the output power fluctuated if there was wind turbulence. In the wind farm setting, the collective output power fluctuation was minimal [5]; however, in a small isolated operation with a weak power network, the impact of power fluctuation on power quality can be significant. In this paper, we do not discuss power quality. Interested readers should refer to the available standard on this issue [6].

The fuel cell was installed to help regulate the frequency in the system. The fuel cell was controlled to produce a unity power factor; thus, the voltage regulation was completely dependent upon excitation of the generator and the capacitors available in the power grid.

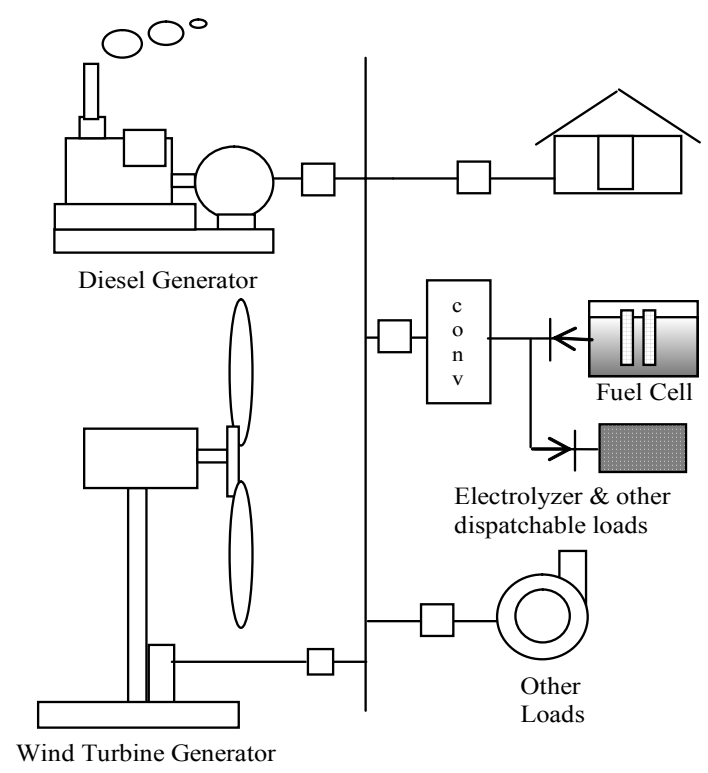

Fig. 1. Physical diagram of the analyzed power system

The load could be divided into three different types. The first was the residential type of load for lighting, heater, or small appliances. The nature of this load was very tolerant to disturbance (i.e., it was immune to low power quality power, fluctuating voltage, and fluctuating frequency). The second type of load was the industrial or heavy load, such as compressors, water pumps, and intermittent large loads. Although insensitive to power quality, this type of load can be the cause of voltage and frequency fluctuations. Another type of load was the dispatchable load, which may consist of an 
electric heater, a battery charger, or an electrolyzer to provide hydrogen to the fuel cell.

\section{COMPonents OF THE POWer System}

The following sections of this paper describe each of the three different power sources: diesel generator, wind-turbine generator, fuel cell.

\section{A. Diesel Generator}

From an electrical system point of view, a diesel generator can be represented as a prime mover and generator. Ideally, the prime mover has the capability to supply any power demand up to rated power at constant frequency. The synchronous generator connected to it must be able to keep the voltage constant at any load condition.

Figure 2 is a block diagram of the diesel generator. The diesel engine kept the frequency constant by maintaining the rotor speed. When power demand fluctuates the diesel generator could vary its output via fuel regulation to its governor. The synchronous generator must control its output voltage by controlling the excitation current. Thus, the diesel generating system, as a unit, must be able to control its frequency and its output voltage. The ability of the diesel generator to respond to frequency changes was affected by the inertia of the diesel gen-set, the sensitivity of the governor, and the power capability of the diesel engine. The ability of the synchronous generator to control its voltage was affected by the field-winding time constant, the availability of the DC power to supply the field winding, and the response of voltage control regulation.

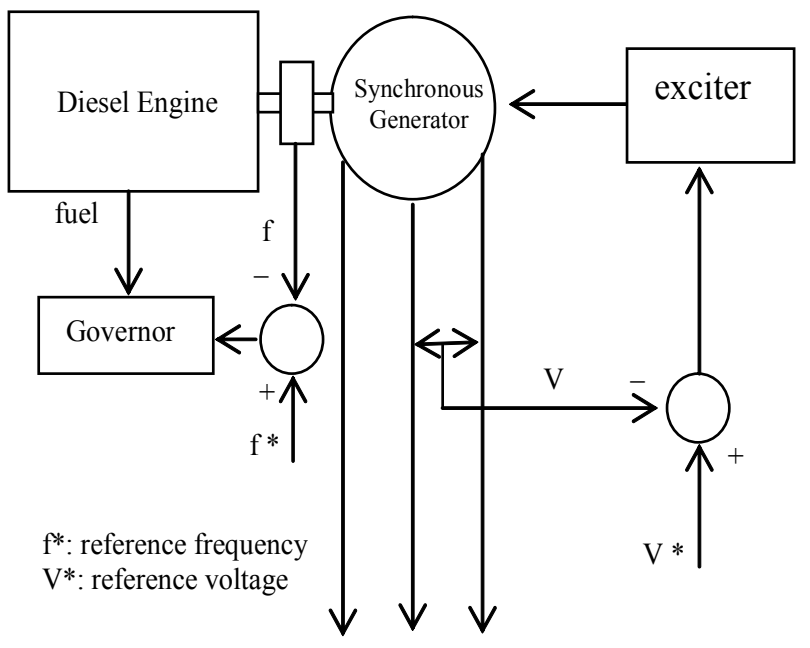

To power network

Fig. 2. Diesel generator Centrol block diagram

\section{B. Wind-Turbine Generator}

The power generated by the wind turbine was defined as follows:

$$
P=0.5 \rho A C_{p} V^{3}
$$

where:

$$
\begin{array}{lll}
\rho & = & \text { density of air } \\
\mathrm{A} & = & \text { swept area of the blade } \\
\mathrm{C}_{\mathrm{p}}= & \text { performance coefficient } \\
\mathrm{V}= & \text { wind speed }
\end{array}
$$

The torque generated by the turbine was represented as:

$T=\frac{P}{\omega_{s}}$

where:

$\mathrm{T}=$ mechanical torque at the turbine side

$\mathrm{P}=$ output power of the turbine

$\omega_{\mathrm{s}}=$ rotor speed of the wind turbine.

A typical $\mathrm{Cp}$ curve characteristic defined $\mathrm{Cp}$ as a function of the tip-speed ratio (TSR) given by equation 3 :

$$
T S R=\frac{\omega_{s} R}{V}
$$

where $\mathrm{R}$ was the radius of the wind turbine rotor. A typical power versus wind speed characteristic of the wind turbine is illustrated in Fig. 3.

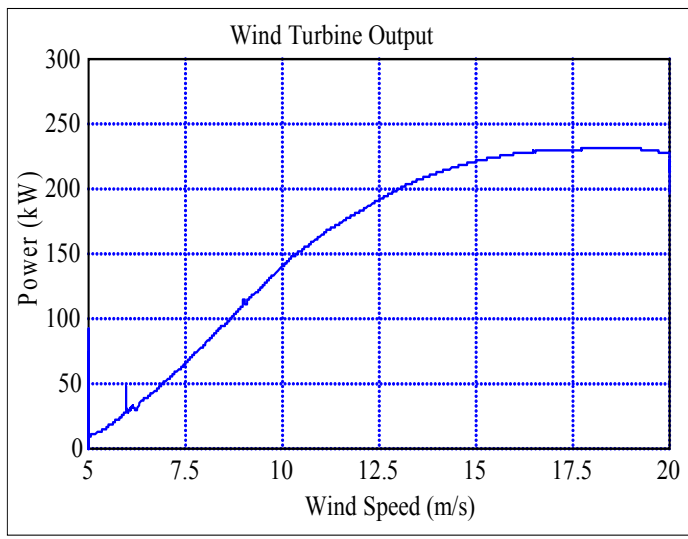

Fig. 3. A typical wind turbine output versus wind speed.

Because this turbine was constant pitch, the wind turbine relied on the blade-stall condition in the high wind speed region to limit the output power. The generator used was an induction generator. Thus, the rotor speed varied within a very small range or was practically constant. In the high speed, the tip speed ratio was expected to be small because the wind speed increased at constant rotor rpm, thus the power coefficient, $\mathrm{Cp}$, was also very small. The output power was self-regulated up to $225 \mathrm{~kW}$. Note that in the higher wind speeds $(>15 \mathrm{~m} / \mathrm{s})$, the output power of the wind turbine was very flat. In the lower wind speeds, the output wind turbine was almost linear.

\section{Fuel Cell}

A group of proton exchange membrane (PEM) fuel-cell stacks were applied to enhance the performance of the hybrid system. The operation principle of PEM fuel cell can be found in the literature, [e.g., 7,8].

A MATLAB/SIMULINK-based dynamic model for the PEM fuel cell [9] was adapted to the Vissim packet [10] for this study. 
A block diagram of the fuel-cell power-generation system that we used is given in Fig. 4. Fuel cell stacks were connected in series/parallel combination to achieve the rating desired. The output of the fuel cell array was connected to a DC bus through a DC/DC converter. The DC bus voltage was kept constant via a DC bus voltage controller. The DC bus voltage was then interfaced with the utility power grid or a custom load through a $\mathrm{DC} / \mathrm{AC}$ inverter, together with its voltage and frequency regulators.

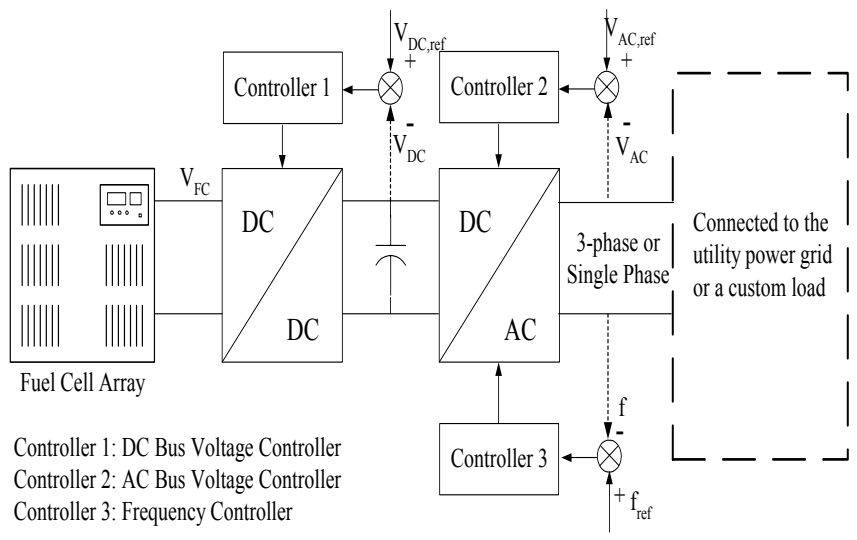

Fig 4. Block diagram of a fuel-cell power system

\section{Dispatchable Load}

We assumed that the dispatchable load was a simple dumpload capable of absorbing real power from the hybrid power system. The purpose of this dump-load was to quickly absorb any excess wind power, thus helping to control the system frequency. In this paper, the dump load was modeled as an adjustable power sink and not modeled as a specific load, such as an electric heater, electrolyzer, battery charger, or a combination of all.

\section{Control Philosophy}

The control philosophy in this system was based on maximizing the nature-dependent energy sources and reducing the diesel fuel consumption. Thus, the power generated by the wind turbine was dictated by the wind, and the diesel and fuel cell were operated to balance the offset between the source and the load consumption. The wind turbine was properly compensated to help with the voltage regulation. Because of the nature of the control of the diesel generator, the diesel generator was used to control the frequency (via its governor) and the output voltage at the power network (via its excitation).

Dispatchable loads, such as an electrolyzer, battery charger, and heater, were deployed as a dumpload to ensure that the generator always carried minimum load, avoiding negative power output of the diesel generator (i.e. thus it is not possible for the wind turbine to drive the synchronous generator into synchronous motor).

\section{A. No Fuel Cell Connected}

In this simulation, no fuel cell contributed to the power system. The power was generated by the diesel generator and the wind turbine. The wind speed varied and so did the power generated by the wind turbine (Fig. 5). The wind speed reached its peak at $14 \mathrm{~s}$ with output power of about $210 \mathrm{~kW}$. The lowest output power was reached at about $34 \mathrm{~s}$. The reactive power compensation was shown to be adequate.

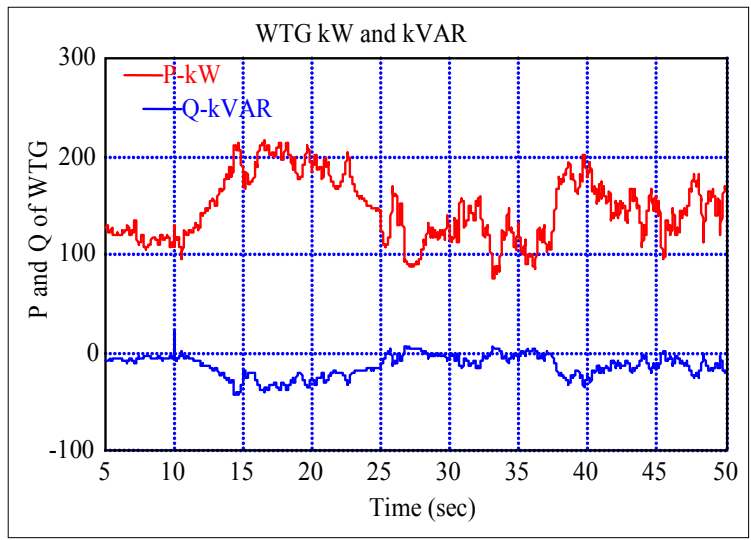

Fig. 5. Real and reactive power output of WTG

Fig. 6 shows the real and reactive power output of the diesel generator. The wind turbine output variation was reflected in the real and reactive power output. The total output of both the diesel generator and the wind turbine output were used to compensate for the load and the water pump. The start-up of the water pump was reflected by power spike at $\mathrm{t}=10 \mathrm{~s}$.

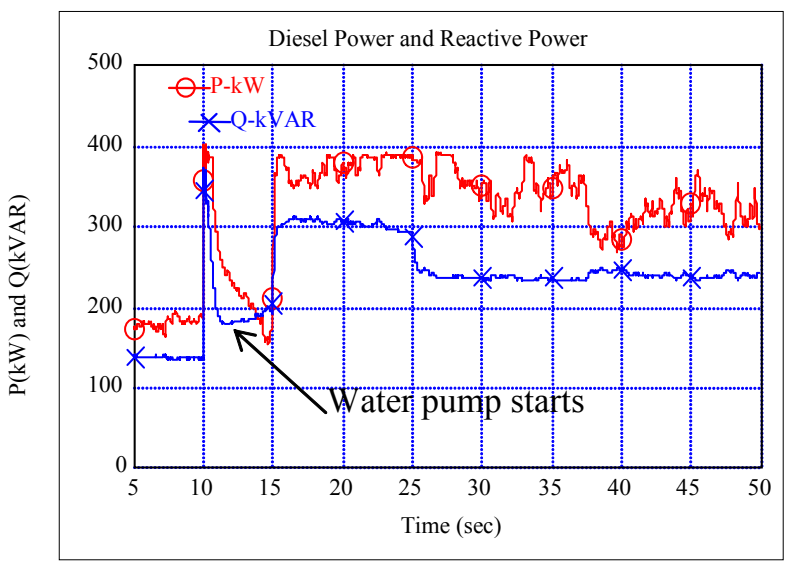

Fig. 6. Real and reactive power output of diesel gen-set

The output power of the diesel generator also exhibited the power required by the village load shown in Fig. 7. The real and reactive power consumed by the village load varied with time, reaching maximum power at $500 \mathrm{~kW}$. This load was modeled as a constant impedance load. Between $\mathrm{t}=23 \mathrm{~s}$ and $t=25 \mathrm{~s}$, the village load was under-served because of lower wind speed during that time frame; the wind turbine generated about $150 \mathrm{~kW}$, the water pump drew $70 \mathrm{~kW}$, and the diesel generator reached its rated power.

The lack of generation in the time frame shown is also reflected by the frequency and voltage traces shown in Fig. 8. The frequency dip shows that there was a sufficient deficiency in power generation that could not be fulfilled by temporarily 
stored energy in the generator inertia, resulting in frequency decline. The frequency returned to normal when the load was reduced to $400 \mathrm{~kW}$. The start-up of the water pump did not affect the frequency very much because the surge during the water pump start-up was very short. The voltage dip, however, was significant as a result of large reactive power demand during water pump start-up. When there was a sudden reduction in village load, both the excitation and the governor of the diesel could not react fast enough, resulting in an increased step in the voltage and frequency (around $\mathrm{t}=25$ s).

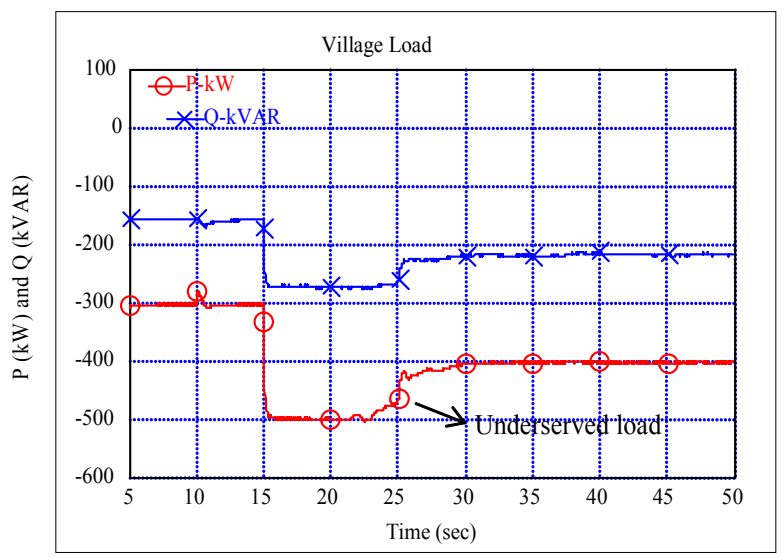

Fig. 7. Village load versus time

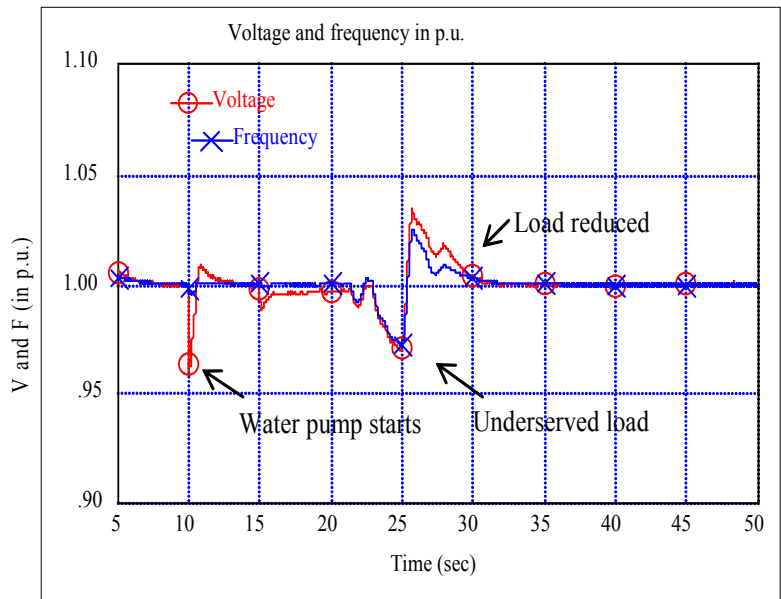

Fig. 8. Voltage and the frequency of the systems

\section{B. Fuel Cell Connected to Support the Load.}

When the fuel cell was connected to the network, the power source came from three different sources. The wind turbine, the diesel generator, and the fuel cell output were combined to supply the load. A comparison of figures 8 and 9 shows the difference in the voltage and the frequency before and after the fuel cell was installed in the system.

During start-up of the water pump, the voltage dip was the same as the voltage dips without the fuel cell installed. The load was fully served during the entire observation. The voltage and frequency dip was previously seen when the load was underserved (between $\mathrm{t}=23 \mathrm{~s}$ and $\mathrm{t}=25 \mathrm{~s}$ ). The load reduction did not show a voltage and frequency jump between $\mathrm{t}=25 \mathrm{~s}$ and $\mathrm{t}=30 \mathrm{~s}$ ) as shown previously when the load was underserved.

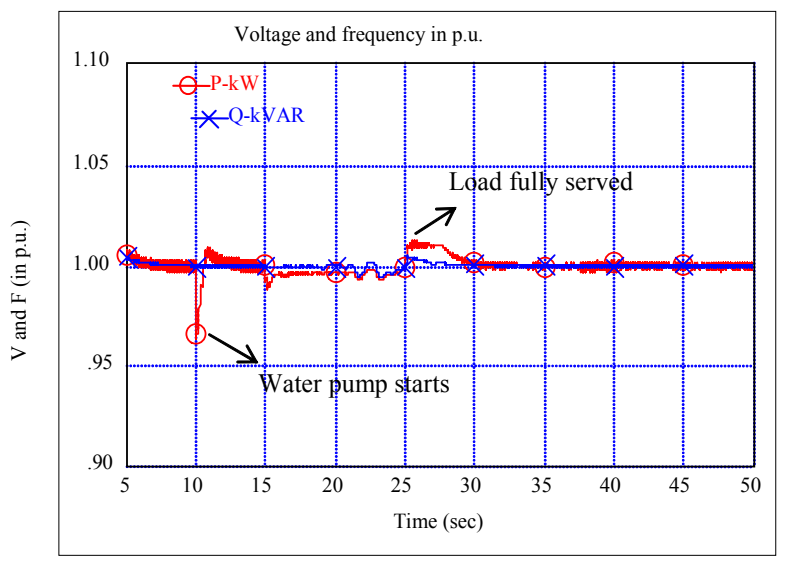

Fig. 9. Voltage and the frequency of the systems with fuel cell installed

As shown in Fig. 10, the village load was fully served as a result of the additional power provided by the fuel cell. It was expected that the fuel cell would compensate for the power dip resulting from the wind power reduction $(t=23 \mathrm{~s})$.

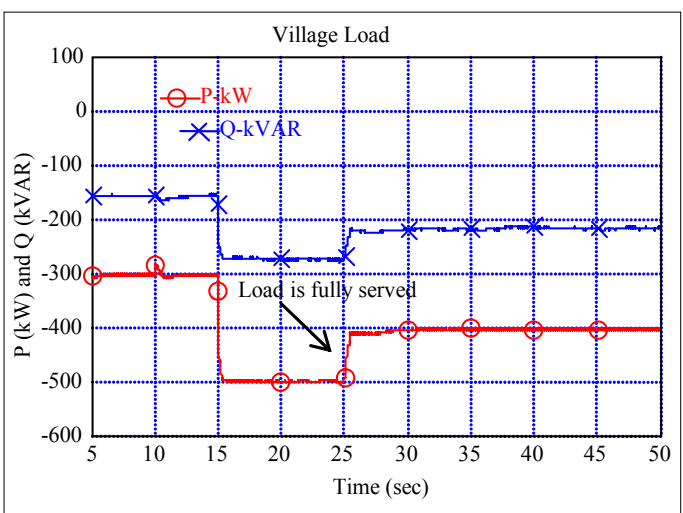

Fig. 10. Village load with fuel cell installed

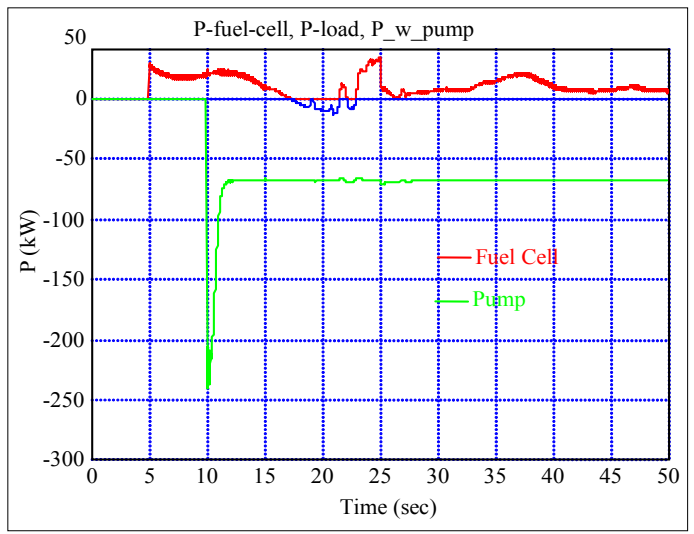

Fig. 11. Output power of fuel cell, water pump

The fuel cell did not respond very well during the start-up of the water pump (Figure 11, sharp increase of load demand), but it did respond appropriately during low wind generation (between $\mathrm{t}=23 \mathrm{~s}$ to $\mathrm{t}=25 \mathrm{~s}$ ) and when the village load was 
reduced (between $t=25$ sto $t=30 \mathrm{~s}$ ). During a very short period of time ( $t=17 \mathrm{~s}$ to $\mathrm{t}=23 \mathrm{~s}$ ), the dump load (shown as negative power) was deployed to prevent the frequency drifting up (during high wind). As mentioned above, the dump load could be substituted with a battery charger or electrolyzer, but this is not modeled at present.

\section{Wind speed is reduced.}

When the wind speed decreased, the power deficit was divided between the two power sources (the diesel and the fuel cell). The fuel cell and the diesel had to generate higher power in order to maintain the power balance in the system.

The wind speed presented in the previous sections was decreased by $3 \mathrm{~m} / \mathrm{s}$. Fig. 12 shows the comparison of the two wind speeds. The impact of reducing the wind speed could be very significant in the lower wind speed region because of the linearity of the wind turbine output in this region. In the higher wind speed, the wind turbine output was very flat (in the stall region); thus, the difference in the output power would not be very significant.

In this scenario, the fuel cell contributed more power to the network. Figure 13 shows that the voltage and frequency regulation was very good. The voltage dip during water pump start-up did not change, and the frequency and voltage during low wind (between $t=23 \mathrm{~s}$ to $\mathrm{t}=25 \mathrm{~s}$ ) and during load reduction (between $\mathrm{t}=25 \mathrm{~s}$ and $\mathrm{t}=30 \mathrm{~s}$ ) was very stable.

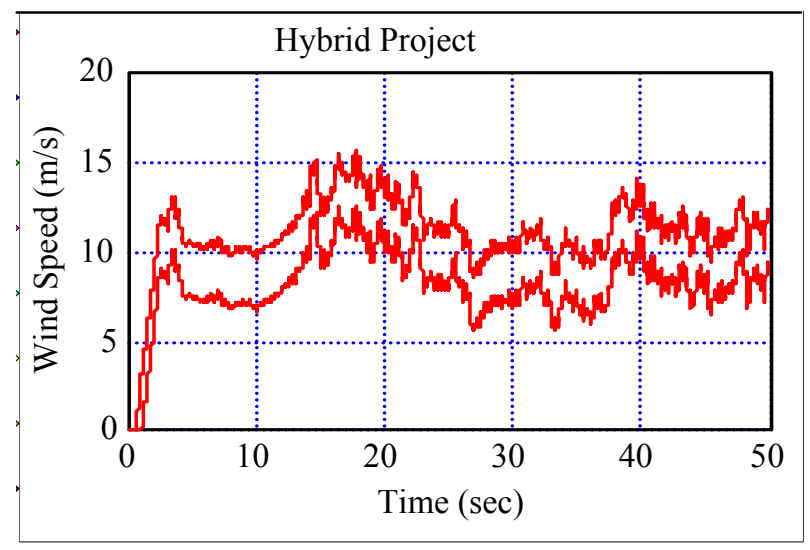

Fig. 12. Wind speed reduced by $3 \mathrm{~m} / \mathrm{s}$

The output power of the wind turbine decreased significantly, especially in the lower wind speed region. The maximum output power of the wind turbine was $200 \mathrm{~kW}$, and the minimum output power of the wind turbine was $50 \mathrm{~kW}$. The contribution of the fuel cell was necessary to compensate for the lack of power generated from the wind turbine. Fig. 14 shows the real and reactive power generated by the wind turbine. The reactive power was shown to be positive at some places. This was possible because the wind turbine was compensated by a fixed capacitor. At lower output (lower slip due to lower winds), the induction generator required less reactive power; thus, there was a small export of reactive power from the wind turbine when it generated lower power.

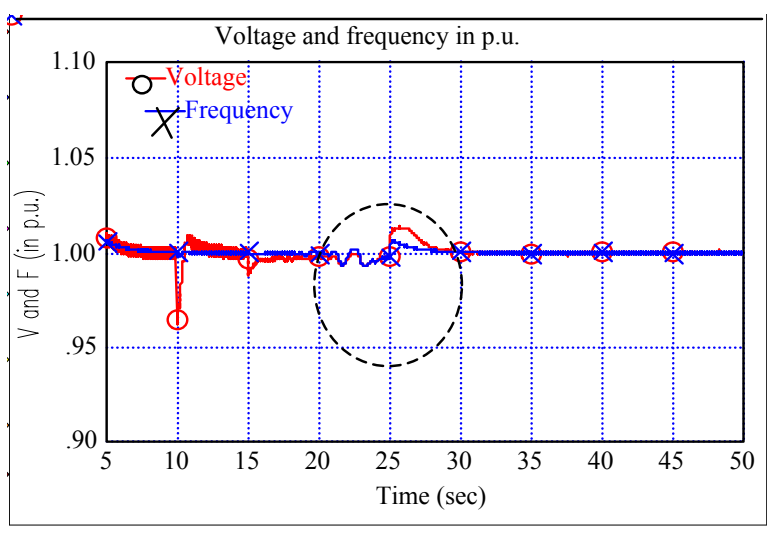

Fig. 13. Voltage and frequency at lower wind speed.

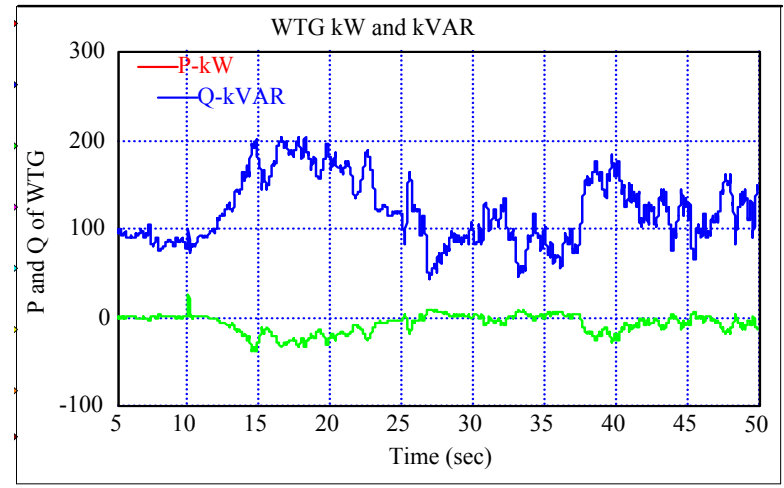

Fig. 14. Real and reactive power of the wind turbine at reduced wind.

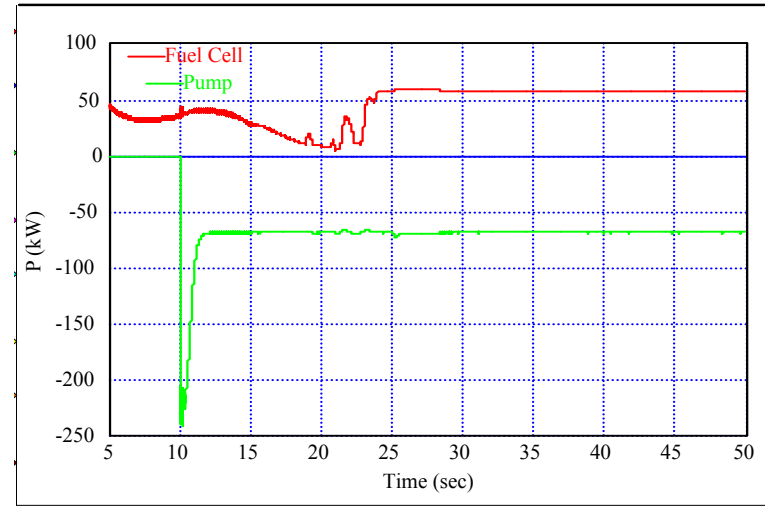

Fig. 15. Fuel cell operation at higher power.

Fig. 15 shows the output of the fuel cell. The fuel cell must operate at higher output power when the wind turbine generation is low. The fuel cell operated at about $60 \mathrm{~kW}$ in the lower wind speed region $(\mathrm{t}>28 \mathrm{~s})$.

\section{CONCLUSION}

This paper investigates the parallel operation of a wind turbine, a diesel generator, and a fuel cell array. The wind turbine contributed significantly to the load, thus reducing the fuel consumption of the diesel generator when the wind speed was available.

In this case study, when the fuel cell was not included, the 
voltage and frequency deviations of the wind/diesel/fuel cell system could be significant, thus affecting the system power quality. The diesel generator had to operate near its rated power, thus limiting its capability to adjust the output frequency. With the fuel cell installed, the system voltage and frequency variations were minimized, and the system had good voltage and frequency regulation.

\section{ACKNOWLEDGMENT}

We acknowledge the support of the U.S. Department of Energy and the National Science Foundation through grant ECS-0135229.

\section{REFERENCES}

[1] Muljadi, E., Flowers, L., Green, J., Bergey, M., "Electrical Design of Wind-Electric Water Pumping," ASME Journal of Solar Energy Engineering, Nov. 1996, Vol. 118, pp. 246-252.

[2] Muljadi, E., McKenna H.E., "Power Quality Issues in a Hybrid Power System," Proceedings of the IEEE Industry Applications Society Conference, Chicago (CD ROM version), September 30 - October 4, 2001.

[3] Tsitsovits, A.J. , Freris, L.L., Dynamics of an Isolated Power System Supplied from Diesel and Wind, Proc. IEEE, 130, Part A, No. 9, pp. 587$595,1983$.

[4] Kunisch, H.J., Kramer, K.G., Dominick, H., "Battery Energy Storage, Another Option for Load-Frequency-Control and Instantaneous Reserve," IEEE Transactions on Energy Conversion, Vol. EC-1, No. 3, September 1986, pp. 41-54.

[5] Muljadi, E., Butterfield, C.P., Gevorgian, V.,"The Impact of the Output Power Fluctuation of a Wind Farm on a Power Grid," Conference Record, Third International Workshop on Transmission Networks for Offshore Wind Farms, Royal Institute of Technology, Stockholm, Sweden, April 11 - 12, 2002.

[6] IEC Standard 61 400-21 Measurement and Assessment of Power Quality of Grid Connected Wind Turbines. International Electrotechnical Commission.

[7] Smith, J.A., Nehrir, M.H., Gerez, V., Shaw, S.R. "A broad look at the workings, types, and applications of fuel cells," Proceedings of 2002 IEEE Power Engineering Society Summer Meeting, Vol. 1, pp. 70-75, July 2002, Chicago IL.

[8] Larminie, J.,Dicks, A., Fuel Cell Systems Explained, John Wiley \& Sons, Ltd., 2001

[9] Wang, C.,Nehrir, M.H., "A Dynamic Model for PEM Fuel Cells Using Electrical Circuit," Proceedings of 35th North American Power Symposium, pp. 30-35, Oct 2003, Rolla, MO.

[10] VisSim/Simulink Translator User's Guide-Version 5, Visual Solutions, Inc, 2002. 


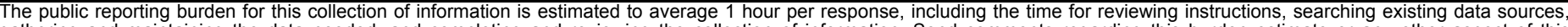

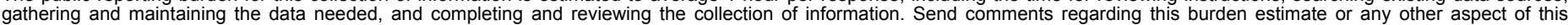

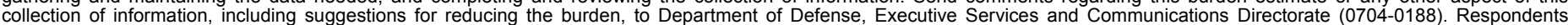

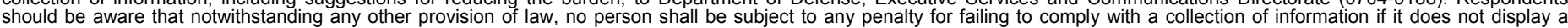

should be aware that notwithstanding

PLEASE DO NOT RETURN YOUR FORM TO THE ABOVE ORGANIZATION.

\begin{tabular}{l|l|l|l} 
1. REPORT DATE $(D D-M M-Y Y Y Y)$ & 2. REPORT TYPE & 3. DATES COVERED (FrOm - TO)
\end{tabular} June 2004

Conference Paper

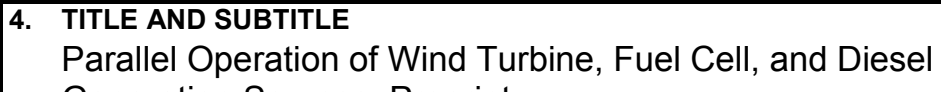

Generation Sources: Preprint

5a. CONTRACT NUMBER

DE-AC36-99-GO10337

5b. GRANT NUMBER

5c. PROGRAM ELEMENT NUMBER

6. AUTHOR(S)

E. Muljadi, C. Wang, and M.H. Nehrir

5d. PROJECT NUMBER

NREL/CP-500-35353

5e. TASK NUMBER

WER47001

5f. WORK UNIT NUMBER
7. PERFORMING ORGANIZATION NAME(S) AND ADDRESS(ES)

National Renewable Energy Laboratory

1617 Cole Blvd.

Golden, CO 80401-3393

9. SPONSORING/MONITORING AGENCY NAME(S) AND ADDRESS(ES)

\section{PERFORMING ORGANIZATION REPORT NUMBER \\ NREL/CP-500-35353}

10. SPONSOR/MONITOR'S ACRONYM(S) NREL

11. SPONSORING/MONITORING AGENCY REPORT NUMBER

12. DISTRIBUTION AVAILABILITY STATEMENT

National Technical Information Service

U.S. Department of Commerce

5285 Port Royal Road

Springfield, VA 22161

13. SUPPLEMENTARY NOTES

14. ABSTRACT (Maximum 200 Words)

We investigated a small isolated hybrid power system that used a parallel combination of dispatchable and nondispatchable power generation sources. The non-dispatchable generation came from a nature-dependent wind turbine, and the dispatchable generations were a fuel cell and a diesel generator. On the load side, the nondispatchable portion was the village load, and the dispatchable portion was the energy storage, which could be in many different forms (e.g., space/water heater, electrolysis, battery charger, etc.) The interaction among different generation sources and the loads was investigated. Simulation results showed the effect of the proposed system on voltage and frequency fluctuations.

15. SUBJECT TERMS

wind turbine, diesel, fuel cell, power generation, parallel operation, hybrid generation

\begin{tabular}{|c|c|c|}
\hline \multicolumn{3}{|c|}{ 16. SECURITY CLASSIFICATION OF: } \\
\hline $\begin{array}{l}\text { a. REPORT } \\
\text { Unclassified }\end{array}$ & $\begin{array}{l}\text { b. ABSTRACT } \\
\text { Unclassified }\end{array}$ & $\begin{array}{l}\text { c. THIS PAGE } \\
\text { Unclassified }\end{array}$ \\
\hline
\end{tabular}

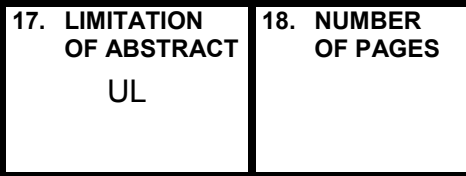

19a. NAME OF RESPONSIBLE PERSON

19b. TELEPONE NUMBER (Include area code) 